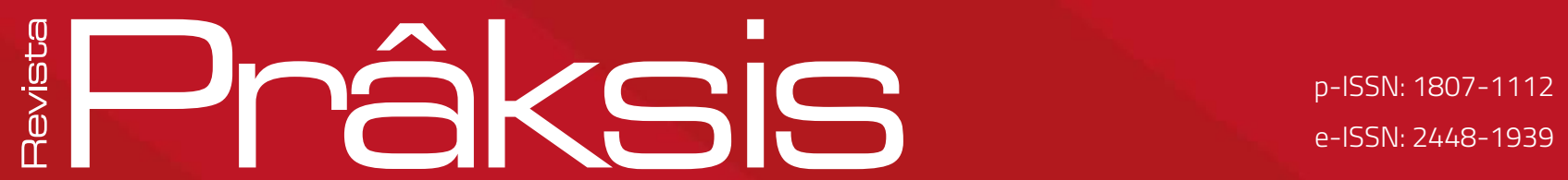

Recebido em: 12 de abril de 2019

Aprovado em: 05 de agosto de 2019

Sistema de Avaliação: Double Blind Review

RPR |a. 16|n. 3 |p. 110-112| set./dez. 2019

DOI: https://doi.org/10.25112/rpr.v3i0.2013

\title{
IT IN EDUCATION: FORESIGHT 2020: ICT COMPETENCY, ENHANCING CITIZENS' MEDIA AND COMPUTER LITERACY
}

TI NA EDUCAÇÃO: PROSPECÇÃO 2020: COMPETÊNCIA EM TIC, APRIMORANDO A ALFABETIZAÇÃO EM MÍDIA E INFORMÁTICA DOS CIDADÃOS

\section{Tapio Varis}

Professor emeritus. Unesco Chair in Global e-learning, University of Tampere, Finland.

E-mail: tapio.varis@uta.fi 
As a new working and learning culture emphasizes the importance of lifelong learning, corporations are beginning to provide workers with means to customize and direct their own learning experiences. There is still a long road to travel in terms of improving employment opportunities for individuals and expanding the innovative capabilities of companies; however, workers, employers and trainers are all becoming more responsible in trying to ensure the continuous development of the knowledge and skills acquired. The traditional focus of vocational education on skills needed for manual work is being challenged by the mixture of competencies required in the workplace today. Many traditional forms of work are undergoing major changes, and as a result the division between manual and mental work is vanishing. Sustainable vocational education should concern and affect both manual and mental competencies.

Today this awareness must be media-related and humanistic. On the one hand, as media-related, its main goal must be to monitor the development of the media and be keenly aware of what it may represent for humanity, for better or for worse. On the other hand, this awareness must drive the values of a new humanism, and it must do so in many senses:

a) In the sense that it must situate the human person at the core of this media civilisation, this new manmade, telecom world around us, just as in the Renaissance the humanists managed to place human beings at the centre of a world which had been organised by theology until then.

b) In the sense that this new awareness must drive the primacy of the critical sense towards technology and thus replace this trusting and rather unselective attitude that prevails today and forces us to unconditionally accept technological innovation. This echoes how the humanists defended a free, critical interpretation of the classical texts and ultimately the autonomy of the intellect and the human person. While Renaissance humanism served as a critical filter of the values of its day by filtering mediaeval culture with classical culture, the new 21st century humanism most foster a critical sense which is alert to the hypertechnologised environment and capable of discerning between what should be kept and what should be revamped.

c) In the sense that while Renaissance humanism helped to "discover" the sense of self and biography and fostered a new form of individual autonomy compared to the sometimes asphyxiating weight of traditionalist thinking, the new humanism must help to foster a sense of autonomy in a context in which global communication can engender dependence and very subtle forms of intellectual subjugation.

d) In the sense that while Renaissance humanism was characterised by a "discovery" of new "worlds", America first and foremost, but also Africa and Asia, giving rise to an "encounter" - often violent - between cultures and civilisations, the new humanism in the global communication society 
must prioritise a new sense of respect for multiplicity and cultural diversity and must support media development with the goal of consolidating the new culture of peace.

e) Finally, in the sense that, just like Renaissance humanism, through the new media and humanistic awareness now is the time for us to be capable of reviving the classical idea of cosmopolitan, universal citizen, with very clear rights and responsibilities, which entail a planet-wide commitment. We must foster a kind of citizenship that stimulates the idea that individuals view themselves as the bearers of universal rights, as well as responsibilities which are also universal.

\section{Reference:}

Available in: <https://iite.unesco.org/news/639368/>. Acess in: sep. 2019. 